\section{JURNAL EKONOMI EFEKTIF}

ISSN : $2622-8882$, E-ISSN : 2622-9935

Jurnal Ekonomi Efektif, Vol. 3, No. 1, Oktober 2020 @Prodi Manajemen Fakultas Ekonomi Universitas Pamulang

\title{
PENGARUH STORE ATMOSPHERE DAN PROMOSI TERHADAP KEPUTUSAN PEMBELIAN PADA ALFAMART BSD TANGERANG SELATAN
}

\author{
Aris Ariyanto $^{1 *}$, Anum Nuryani ${ }^{2}$, Denok Sunarsi ${ }^{3}$ \\ Universitas Pamulang \\ dosen02492@unpam.ac.id*
}

\begin{abstract}
ABSTRAK
Penelitian ini bertujuan untuk mengetahui pengaruh Store Atmosphere dan promosi terhadap keputusan pembelian pada Alfamart BSD Tangerang Selatan. Metode yang digunakan adalah explanatory research dengan teknik analisis menggunakan analisis statistik dengan pengujian regresi, korelasi, determinasi dan uji hipotesis. Hasil penelitian ini Store Atmosphere berpengaruh signifikan terhadap keputusan pembelian sebesar 40,5\%, uji hipotesis diperoleh $\mathrm{t}$ hitung $>\mathrm{t}$ tabel atau $(8,003>1,986)$. Promosi berpengaruh signifikan terhadap keputusan pembelian sebesar 50,3\%, uji hipotesis diperoleh $\mathrm{t}$ hitung $>\mathrm{t}$ tabel atau $(9,746>$ 1,986). Store Atmosphere dan promosi secara simultan berpengaruh signifikan terhadap keputusan pembelian dengan persamaan regresi $\mathrm{Y}=9,701+0,326 \mathrm{X} 1+0,441 \mathrm{X} 2$ dan kontribusi pengaruh sebesar 55,9\%, uji hipotesis diperoleh $\mathrm{F}$ hitung > F tabel atau $(59,045>$ 2,700).
\end{abstract}

\section{Kata Kunci: Store Atmosphere, Promosi, Keputusan Pembelian.}

\begin{abstract}
This study aims to determine the effect of Store Atmosphere and promotion on purchasing decisions at Alfamart BSD Tangerang Selatan. The method used is explanatory research with analysis techniques using statistical analysis with regression testing, correlation, determination and hypothesis testing. The results of this study Store Atmosphere has a significant effect on purchasing decisions by 40.5\%, hypothesis testing obtained $t$ count $>t$ table or (8.003> 1.986). Promotion has a significant effect on purchasing decisions by 50.3\%, hypothesis testing is obtained $t$ count $>t$ table or (9.746> 1.986). Store atmosphere and promotion simultaneously have a significant effect on purchasing decisions with the regression equation $Y=9,701+0,326 X 1+0,441 X 2$ and the contribution of the effect is 55,9\%, hypothesis testing obtained $F$ count $>F$ table or $(59,045>2,700)$.
\end{abstract}

Keywords: Store Atmosphere, Promotion, Purchase Decision. 


\section{PENDAHULUAN}

\section{A. Latar Belakang Masalah}

Pertumbuhan perekonomian dan perkembangan zaman khususnya Indonesia telah semakin modern, berdampak pada pergeseran budaya berbelanja masyarakat di Indonesia. Hal ini terlihat jelas dan dapat dibuktikan dengan adanya perubahan gaya hidup masyarakat yang dahulu berbelanja di pasar tradisional, namun pada saat ini masyarakat Indonesia lebih suka dan memilih berbelanja di pasar modern seperti hypermarket, minimarket dan lain-lain. Pergeseran tingkah laku dan pola konsumsi masyarakat yang berubah seperti saat ini seiring dengan peningkatan pendapatan masyarakat sehingga menyebabkan pula peningkatan pada kebutuhan masyarakat. Perilaku konsumen tersebut merupakan salah satu faktor yang dapat memicu berkembangnya bisnis retail modern di Indonesia. Maka dari itu hal tersebut menjadi peluang besar bagi para pembisnis khususnya retail modern.

Store atmosphere (suasana toko) adalah kegiatan mendesain lingkungan toko yang menarik dan memberikan kesan bagi konsumen. Utami (2006:229) menjelasakan bahwa mendesain toko dengan baik sama halnya membuat sebuah cerita yang menarik bagi pembaca,desain toko yang baik akan menarik keinginan konsumen untuk mengetahui lebih dalam segala sesuatu yang ditawarkan oleh toko tersebut. Suasana toko dapat dibangun melalui sistem pencahayaan, pengaturan tata letak, dan penataan atau pengaturan produk yang baik yang akan menarik konsumen.

Promosi adalah upaya untuk memberitahukan atau menawarkan produk atau jasa pada dengan tujuan menarik calon konsumen untuk membeli atau mengkonsumsinya. Dengan adanya promosi produsen atau distributor mengharapkan kenaikannya angka penjualan. Menurut Utami (2006:31), promosi adalah penjualan terorganisasi yang memberikan konsumen sebuah insentif agar membeli produk tertentu, promosi yang dilakukan dengan memberikan insentif memiliki tujuan awal yaitu menarik minat konsumen.

Kegiatan promosi yang diadakan oleh Alfamart di BSD Tangerang Selatan merupakan salah satu cara yang dapat menarik pembelian konsumen bahkan menimbulkan pembelian tak terduga oleh konsumen. Kegiatan promosi yang diberikan cukup bervariasi mulai dari discount harga $50 \%, 20 \%$, beli 1 gratis 1 , beli 2 gratis 1 , dan masih banyak lagi acara discount yang menarik lainnya. Harapan dengan adanya discount tersebut dapat mempengaruhi keputusan pembelian di Alfamart serta mempengaruhi konsumen untuk semakin banyak berbelanja sehingga dapat menaikkan penjualan.

Berdasarkan latar belakang masalah di atas, maka penulis tertarik untuk melakukan penelitian berjudul "Pengaruh Store Atmosphere dan Promosi Terhadap Keputusan Pembeian di Alfamart BSD Tangerang Selatan".

\section{B. Rumusan Masalah}

1. Adakah pengaruh antara Store Atmosphere terhadap keputusan pembelian pada Alfamart BSD Tangerang Selatan?

2. Adakah pengaruh antara promosi terhadap keputusan pembelian pada Alfamart BSD Tangerang Selatan?

3. Adakah pengaruh secara simultan antara Store Atmosphere dan promosi terhadap keputusan pembelian pada Alfamart BSD Tangerang Selatan?

\section{Tujuan Penelitian}

1. Untuk mengetahui pengaruh antara Store Atmosphere terhadap keputusan pembelian pada Alfamart BSD Tangerang Selatan. 
2. Untuk mengetahui pengaruh antara promosi terhadap keputusan pembelian pada Alfamart BSD Tangerang Selatan.

3. Untuk mengetahui pengaruh secara simultan antara Store Atmosphere dan promosi terhadap keputusan pembelian pada Alfamart BSD Tangerang Selatan

\section{METODE PENELITIAN}

\section{Populasi}

Populasi dalam penelitian ini berjumlah 96 responden Alfamart BSD Tangerang Selatan

\section{Sampel}

Sampel dalam penelitian ini berjumlah 96 responden.

\section{Jenis Penelitian}

Jenis penelitian yang dipakai adalah asosiatif, dimana tujuannya adalah untuk mengetahui pengaruh antara variabel bebas terhadap variabel terikat baik parsial maupun simultan

\section{Metode Analisis Data}

Dalam menganalisis data digunakan uji instrumen, uji asumsi klasik, regresi, koefisien determinasi dan uji hipotesis.

\section{HASIL PENELITIAN DAN PEMBAHASAN}

\section{Analisis Deskriptif}

Pada pengujian ini digunakan untuk mengetahui skor minimum dan maksimum, mean score dan standar deviasi dari masing-masing variabel. Adapun hasilnya sebagai berikut:

Tabel 1. Hasil Analisis Descriptive Statistics Descriptive Statistics

\begin{tabular}{|l|r|r|r|r|r} 
& N & Minimum & Maximum & Mean & \multicolumn{1}{c}{ Std. Deviation } \\
\hline Store Atmosphere (X1) & 96 & 32 & 48 & 38.24 & 3.960 \\
\hline Promosi (X2) & 96 & 30 & 47 & 38.56 & 3.879 \\
\hline Keputusan pembelian (Y) & 96 & 31 & 47 & 39.06 & 3.673 \\
\hline Valid N (listwise) & 96 & & & & \\
\hline
\end{tabular}

Store Atmosphere diperoleh varians minimum sebesar 32 dan varians maximum 48 dengan mean score sebesar 38,24 dengan standar deviasi 3,960.

Promosi diperoleh varians minimum sebesar 30 dan varians maximum 47 dengan mean score sebesar 38,56 dengan standar deviasi 3,879.

Keputusan pembelian diperoleh varians minimum sebesar 31 dan varians maximum 47 dengan mean score sebesar 39,06 dengan standar deviasi 3,673.

\section{Analisis Verifikatif.}

Pada analisis ini dimaksudkan untuk mengetahui pengaruh variabel independen terhadap variabel dependen. Adapun hasil pengujian sebagai berikut:

\section{a. Analisis Regresi Linier Berganda}

Uji regresi ini dimaksudkan untuk mengetahui perubahan variabel dependen jika variabel independen mengalami perubahan. Adapun hasil pengujiannya sebagai berikut:

\begin{tabular}{|c|c|c|c|c|c|}
\hline \multirow[b]{3}{*}{ Model } & \multicolumn{3}{|c|}{ Coefficients $^{a}$} & \multirow[b]{3}{*}{$\mathrm{t}$} & \multirow[b]{3}{*}{ Sig. } \\
\hline & \multicolumn{2}{|c|}{$\begin{array}{l}\text { Unstandardized } \\
\text { Coefficients }\end{array}$} & \multirow{2}{*}{$\begin{array}{c}\text { Standardized } \\
\text { Coefficients } \\
\text { Beta }\end{array}$} & & \\
\hline & $\mathrm{B}$ & Std. Error & & & \\
\hline 1 (Constant) & 9.701 & 2.876 & & 3.374 & .001 \\
\hline
\end{tabular}




\begin{tabular}{l|l|l|l|l|r}
\hline Store Atmosphere $(\mathrm{X} 1)$ & .326 & .079 & .375 & 4.141 & .000 \\
\hline Promosi $(\mathrm{X} 2)$ & .441 & .086 & .462 & 5.105 & .000 \\
\hline
\end{tabular}

a. Dependent Variable: Keputusan pembelian (Y)

Berdasarkan hasil pengujian pada tabel di atas, diperoleh persamaan regresi $Y$ $=9,701+0,326 \mathrm{X} 1+0,441 \mathrm{X} 2$. Dari persamaan tersebut dijelaskan sebagai berikut:

1) Konstanta sebesar 9,701 diartikan jika Store Atmosphere dan promosi tidak ada, maka telah terdapat nilai keputusan pembelian sebesar 9,701 point.

2) Koefisien regresi Store Atmosphere sebesar 0,326, angka ini positif artinya setiap ada peningkatan Store Atmosphere sebesar 0,326 maka keputusan pembelian juga akan mengalami peningkatan sebesar 0,326 point.

3) Koefisien regresi promosi sebesar 0,441 , angka ini positif artinya setiap ada peningkatan promosi sebesar 0,441 maka keputusan pembelian juga akan mengalami peningkatan sebesar 0,441 point.

\section{b. Analisis Koefisien Korelasi}

Analisis koefisien korelasi dimaksudkan untuk mengetahui tingkt kekuatan hubungan dari variabel independen terhadap variabel dependen baik secara parsial maupun simultan. Adapun hasil pengujian sebagai berikut:

Tabel 3. Hasil Pengujian Koefisien Korelasi Store Atmosphere Terhadap Keputusan pembelian.

\begin{tabular}{|c|c|c|c|}
\hline \multicolumn{4}{|c|}{ Correlations $^{b}$} \\
\hline & & $\begin{array}{c}\text { Store } \\
\text { Atmosphere (X1) }\end{array}$ & $\begin{array}{c}\text { Keputusan } \\
\text { pembelian (Y) }\end{array}$ \\
\hline \multirow[t]{2}{*}{ Store Atmosphere (X1) } & Pearson Correlation & 1 & $.637^{* \star}$ \\
\hline & Sig. (2-tailed) & & .000 \\
\hline \multirow[t]{2}{*}{ Keputusan pembelian (Y) } & Pearson Correlation & $.637^{* *}$ & 1 \\
\hline & Sig. (2-tailed) & .000 & \\
\hline
\end{tabular}

Berdasarkan hasil pengujian diperoleh nilai korelasi sebesar 0,637 artinya Store Atmosphere memiliki hubungan yang kuat terhadap keputusan pembelian.

Tabel 4. Hasil Pengujian Koefisien Korelasi Promosi Terhadap Keputusan pembelian.

\begin{tabular}{|c|c|c|c|}
\hline \multicolumn{4}{|c|}{ Correlations $^{b}$} \\
\hline & & Promosi (X2) & $\begin{array}{c}\text { Keputusan } \\
\text { pembelian (Y) }\end{array}$ \\
\hline \multirow[t]{2}{*}{ Promosi (X2) } & Pearson Correlation & 1 & $.709^{* \star}$ \\
\hline & Sig. (2-tailed) & & .000 \\
\hline \multirow{2}{*}{$\begin{array}{l}\text { Keputusan pembelian } \\
\text { (Y) }\end{array}$} & Pearson Correlation & $.709^{* \star}$ & 1 \\
\hline & Sig. (2-tailed) & .000 & \\
\hline
\end{tabular}

Berdasarkan hasil pengujian diperoleh nilai korelasi sebesar 0,709 artinya promosi memiliki hubungan yang kuat terhadap keputusan pembelian.

Tabel 5. Hasil Pengujian Koefisien Korelasi Store Atmosphere dan Promosi secara simultan Terhadap Keputusan pembelian. Model Summary

\begin{tabular}{|c|c|c|c|c|}
\hline \multirow{3}{*}{$\frac{\text { Model }}{1}$} & \multicolumn{4}{|c|}{ Model Summary } \\
\hline & $\mathrm{R}$ & R Square & $\begin{array}{l}\text { Adjusted R } \\
\text { Square }\end{array}$ & $\begin{array}{l}\text { Std. Error of the } \\
\text { Estimate }\end{array}$ \\
\hline & $.748^{\mathrm{a}}$ & .559 & .550 & 2.464 \\
\hline
\end{tabular}

Berdasarkan hasil pengujian diperoleh nilai korelasi sebesar 0,748 artinya Store Atmosphere dan promosi secara simultan memiliki hubungan yang kuat terhadap keputusan pembelian. 


\section{c. Analisis Koefisien Determinasi}

Analisis koefisien determinasi dimaksudkan untuk mengetahui besarnya persentase pengaruh dari variabel independen terhadap variabel dependen baik secara parsial maupun simultan. Adapun hasil pengujian sebagai berikut:

Tabel 6. Hasil Pengujian Koefisien Determinasi Store Atmosphere Terhadap

Keputusan pembelian. Model Summary

\begin{tabular}{lrr|rr|r} 
Model & \multicolumn{2}{c}{} & \multicolumn{2}{c}{$\begin{array}{c}\text { Adjusted R } \\
\text { Square }\end{array}$} & \multicolumn{2}{c}{$\begin{array}{c}\text { Std. Error of the } \\
\text { Estimate }\end{array}$} \\
\hline 1 & $\mathrm{R}$ & R Square & .405 & .399 & 2.848 \\
\hline a. Predictors: (Constant), Store Atmosphere $(\mathrm{X} 1)$ & &
\end{tabular}

a. Predictors: (Constant), Store Atmosphere (X1)

Berdasarkan hasil pengujian diperoleh nilai determinasi sebesar 0,405 artinya Store Atmosphere memiliki kontribusi pengaruh sebesar 40,5\% terhadap keputusan pembelian.

Tabel 7. Hasil Pengujian Koefisien Determinasi Promosi Terhadap Keputusan

\section{Pembelian.}

Model Summary

\begin{tabular}{|c|c|c|c|c|}
\hline Model & $\mathrm{R}$ & R Square & $\begin{array}{l}\text { Adjusted R } \\
\text { Square } \\
\end{array}$ & $\begin{array}{l}\text { Std. Error of the } \\
\text { Estimate }\end{array}$ \\
\hline 1 & $.709^{a}$ & .503 & .497 & 2.604 \\
\hline
\end{tabular}

Berdasarkan hasil pengujian diperoleh nilai determinasi sebesar 0,503 artinya promosi memiliki kontribusi pengaruh sebesar 50,3\% terhadap keputusan pembelian.

Tabel 8. Hasil Pengujian Koefisien Determinasi Store Atmosphere dan Promosi Terhadap Keputusan pembelian. Model Summary

\begin{tabular}{|c|c|c|c|c|}
\hline \multicolumn{5}{|c|}{ Adiusted $\mathrm{B}$} \\
\hline Model & $\mathrm{R}$ & R Square & $\begin{array}{l}\text { Adjusted R } \\
\text { Square }\end{array}$ & $\begin{array}{l}\text { Std. Error of the } \\
\text { Estimate }\end{array}$ \\
\hline 1 & $.748^{\mathrm{a}}$ & .559 & .550 & 2.46 \\
\hline
\end{tabular}

a. Predictors: (Constant), Promosi (X2), Store Atmosphere (X1)

Berdasarkan hasil pengujian diperoleh nilai determinasi sebesar 0,559 artinya Store Atmosphere dan promosi secara simultan memiliki kontribusi pengaruh sebesar $55,9 \%$ terhadap keputusan pembelian, sedangkan sisanya sebesar $44,1 \%$ dipengaruhi faktor lain.

\section{d. Uji Hipotesis}

\section{Uji hipotesis Parsial (Uji t)}

Pengujian hipotesis dengan uji t digunakan untuk mengetahui hipotesis parsial mana yang diterima.

Hipotesis pertama: Terdapat pengaruh yang signifikan antara Store Atmosphere terhadap keputusan pembelian.

Tabel 9. Hasil Uji Hipotesis Store Atmosphere Terhadap Keputusan pembelian. Coefficients $^{\mathrm{a}}$

\begin{tabular}{|c|c|c|c|c|c|}
\hline \multirow[b]{3}{*}{ Model } & \multicolumn{2}{|c|}{ CUeIIICICIIS } & \multirow[b]{2}{*}{$\begin{array}{l}\text { Standardized } \\
\text { Coefficients }\end{array}$} & & \multirow[b]{3}{*}{ Sig. } \\
\hline & $\begin{array}{r}\text { Unsta } \\
\text { Coe }\end{array}$ & $\begin{array}{l}\text { dardized } \\
\text { ficients }\end{array}$ & & & \\
\hline & B & Std. Error & Beta & & \\
\hline 1 (Constant) & 16.482 & 2.836 & & 5.811 & .000 \\
\hline Store Atmosphere (X1) & .591 & .074 & .637 & 8.003 & . 000 \\
\hline
\end{tabular}

Berdasarkan hasil pengujian pada tabel di atas, diperoleh nilai t hitung $>\mathrm{t}$ tabel atau $(8,003>1,986)$, dengan demikian hipotesis pertama yang diajukan bahwa terdapat pengaruh yang signifikan atara Store Atmosphere terhadap keputusan pembelian diterima. 
Tabel 10. Hasil Uji Hipotesis Promosi Terhadap Keputusan pembelian. Coefficients $^{\mathrm{a}}$

\begin{tabular}{|c|c|c|c|c|c|c|}
\hline \multirow{3}{*}{\multicolumn{2}{|c|}{ Model }} & & \multirow{3}{*}{$\begin{array}{c}\text { Standardized } \\
\text { Coefficients } \\
\text { Beta }\end{array}$} & \multirow[b]{3}{*}{$t$} & \multirow[b]{3}{*}{ Sig. } \\
\hline & & \multicolumn{2}{|c|}{$\begin{array}{l}\text { Unstandardized } \\
\text { Coefficients }\end{array}$} & & & \\
\hline & & $\mathrm{B}$ & Std. Error & & & \\
\hline \multirow{2}{*}{\multicolumn{2}{|c|}{$\begin{array}{l}\text { (Constant) } \\
\text { Promosi (X2) }\end{array}$}} & 13.178 & 2.669 & & 4.937 & .000 \\
\hline & & .671 & .069 & .709 & 9.746 & .000 \\
\hline
\end{tabular}

a. Dependent Variable: Keputusan pembelian (Y)

Berdasarkan hasil pengujian pada tabel di atas, diperoleh nilai $\mathrm{t}$ hitung $>\mathrm{t}$ tabel atau $(9,746>1,986)$, dengan demikian hipotesis kedua yang diajukan bahwa terdapat pengaruh yang signifikan atara promosi terhadap keputusan pembelian diterima.

\section{Uji Hipotesis Simultan (Uji F)}

Pengujian hipotesis dengan uji $\mathrm{F}$ digunakan untuk mengetahui hipotesis simultan yang mana yang diterima.

Hipotesis ketiga Terdapat pengaruh yang signifikan antara Store Atmosphere dan promosi terhadap keputusan pembelian.

Tabel 11. Hasil Uji Hipotesis Store Atmosphere dan Promosi Terhadap Keputusan pembelian.

\begin{tabular}{|c|c|c|c|c|c|c|}
\hline \multicolumn{7}{|c|}{ ANOVA } \\
\hline Model & & Sum of Squares & df & Mean Square & $\mathrm{F}$ & Sig. \\
\hline \multirow[t]{3}{*}{1} & Regression & 716.981 & 2 & 358.490 & 59.045 & $.000^{\mathrm{b}}$ \\
\hline & Residual & 564.644 & 93 & 6.071 & & \\
\hline & Total & 1281.625 & 95 & & & \\
\hline
\end{tabular}

Berdasarkan hasil pengujian pada tabel di atas, diperoleh nilai $\mathrm{F}$ hitung $>\mathrm{F}$ tabel atau $(59,045>2,700)$, dengan demikian hipotesis ketiga yang diajukan bahwa terdapat pengaruh yang signifikan atara Store Atmosphere dan promosi terhadap keputusan pembelian diterima.

\section{PEMBAHASAN HASIL PENELITIAN}

\section{Pengaruh Store Atmosphere Terhadap Keputusan pembelian}

Store Atmosphere berpengaruh signifikan terhadap keputusan pembelian dengan korelasi sebesar 0,637 atau memiliki hubungan yang kuat dengan kontribusi pengaruh sebesar 40,5\%. Pengujian hipotesis diperoleh nilai t hitung $>\mathrm{t}$ tabel atau $(8,003>1,986)$. Dengan demikian hipotesis pertama yang diajukan bahwa terdapat berpengaruh signifikan antara Store Atmosphere terhadap keputusan pembelian diterima.

\section{Pengaruh Promosi Terhadap Keputusan pembelian}

Promosi berpengaruh signifikan terhadap keputusan pembelian dengan korelasi sebesar 0,709 atau memiliki hubungan yang kuat dengan kontribusi pengaruh sebesar $50,3 \%$. Pengujian hipotesis diperoleh nilai t hitung $>t$ tabel atau $(9,746>1,986)$. Dengan demikian hipotesis kedua yang diajukan bahwa terdapat berpengaruh signifikan antara promosi terhadap keputusan pembelian diterima.

\section{Pengaruh Store Atmosphere dan Promosi Terhadap Keputusan pembelian}

Store Atmosphere dan promosi berpengaruh signifikan terhadap keputusan pembelian dengan diperoleh persamaan regresi $\mathrm{Y}=9,701+0,326 \mathrm{X} 1+0,441 \mathrm{X} 2$, nilai korelasi sebesar 0,748 atau memiliki hubungan yang kuat dengan kontribusi pengaruh sebesar 55,9\% sedangkan sisanya sebesar 44,1\% dipengaruhi faktor lain. Pengujian hipotesis diperoleh nilai $\mathrm{F}$ hitung $>\mathrm{F}$ tabel atau $(59,045>2,700)$. Dengan demikian hipotesis ketiga yang diajukan bahwa terdapat berpengaruh signifikan antara Store Atmosphere dan promosi terhadap keputusan pembelian diterima. 


\section{PENUTUP}

\section{Kesimpulan}

a. Store Atmosphere berpengaruh signifikan terhadap keputusan pembelian dengan kontribusi pengaruh sebesar 40,5\%. Uji hipotesis diperoleh nilai t hitung $>t$ tabel atau $(8,003>1,986)$.

b. Promosi berpengaruh signifikan terhadap keputusan pembelian dengan kontribusi pengaruh sebesar 50,3\%. Uji hipotesis diperoleh nilai t hitung $>\mathrm{t}$ tabel atau $(9,746>$ 1,986).

c. Store Atmosphere dan promosi berpengaruh signifikan terhadap keputusan pembelian dengan kontribusi pengaruh sebesar 55,9\% sedangkan sisanya sebesar 44,1\% dipengaruhi faktor lain. Uji hipotesis diperoleh nilai $\mathrm{F}$ hitung $>\mathrm{F}$ tabel atau $(59,045>$ $2,700)$.

\section{Saran}

a. Perusahaan harus menegakkan peraturan dengan baik sesuai dengan ketentuan yang berlaku guna menjamin pegawai diperlakukan dengan adil.

b. Perusahaan harus selalu memberikan semangat dan apresiasi yang layak untuk memastikan pegawai memiliki semangat kerja yang tinggi.

c. Kinerja perusahaan dapat ditingkatkan dengan memberdayakan pegawai dengan menegakkan peraturan yang baik dan pemberian promosi yang lebih inten lagi.

\section{DAFTAR PUSTAKA}

Arikunto, Suharsimi (2014). “Prosedur Penelitian Suatu Pendekatan Praktek”. Jakarta: Rineka Cipta.

Basu Swastha Dharmmesta. (2014). Manajemen Pemasaran. BPFE: Yogyakarta.

Bilson Simamora (2016) Panduan Riset Prilaku Konsumen, Jakarta: PT. Gramedia Pustaka.

Fandy Tjiptono (2017), Serivce Quality and Satisfiation. Jakarta: Edisi tiga. Andi.

Freddy Rangkuti (2016) Strategi Promosi Yang Kreatif, Edisi Pertama, Cetakan Pertama Jakarta: Gramedia Pustaka Utama.

Jasmani, J. (2018). Pengaruh Kualitas Produk Dan Harga Terhadap Keputusan Pembelian Pada PT. Baja Mandiri Di Jakarta. Disrupsi Binis, 1(1).

Jasmani, J., \& Sunarsi, D. (2020). The Influence of Product Mix, Promotion Mix and Brand Image on Consumer Purchasing Decisions of Sari Roti Products in South Tangerang. PINISI Discretion Review, 1(1), 165-174.

Kharis, Ismu Fadli (2011). "Studi Mengenai Impulse Buying dalam Penjualan Online”. Semarang : Skripsi Universitas Diponegoro

Kotler dan Amstrong (2017), Prinsip-prinsip Pemasaran. Edisi Kedua Belas”. Jilid Satu. Jakarta: Erlangga.

Lupiyoadi (2016) Manajemen Pemasaran Jasa, Edisi 4, Jakarta: Salemba Empat.

Prasada, D., Sunarsi, D., \& Teriyan, A. (2020). Pengaruh Etos Kerja Dan Kompensasi Terhadap Komitmen Organisasi Pada DHL Logistic Di Jakarta. JENIUS (Jurnal Ilmiah Manajemen Sumber Daya Manusia), 4(1), 51-60.

Rao, Purba, (2012). "Measuring Consumer Perceptions Through Factor Analysis", The Asian.

Santoso, Singgih (2015). "Menguasai Statistik Multivariat”. Jakarta: PT Elex Media Komputindo.

Sugiyono (2017), "Metode Penelitian Administrasi : dilengkapi dengan Metode $R \&$ D”. Bandung: Alfabeta. 
Suhartanto (2014). "Metode Riset Pemasaran”. Bandung: Alfabeta

Sunarsi, D. (2019). Pengaruh Kompetensi, Pengembangan Karir dan Lingkungan Kerja Terhadap Kepuasan Kerja Karyawan Pada PT. Boga Lestari Sentosa Indonesia (Kenny Rogers Roasters).

Sunarsi, D., \& Baharuddin, A. (2019). The Effect of Service Quality and Price Accuracy on Consumer Confidence and Implications for Sales Increase. PINISI Discretion Review, 3(2), 101-110.

Sunarsi, D., Winata, H., Gunartin, G., \& Paeno, P. (2020). Analisis Gaya Kepemimpinan Kepala Desa Dalam Pengembangan Desa Cidokom Gunung Sindur Kabupaten Bogor. Jurnal Ekonomi Efektif, 2(3).

Yusuf, A. D Sunarsi. (2020). The Effect of Promotion and Price on Purchase Decisions. Almana: Jurnal Manajemen dan Bisnis 4 (2), 272-279 